Historic, Archive Document

Do not assume content reflects current scientific knowledge, policies, or practices. 


\section{HARDY WILD FLOWERS FROM MONTANA}

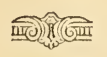

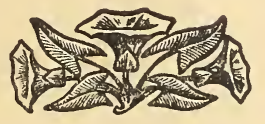

프)过(ن)

Mrs. Albert Obergfell Sidney, Montana 


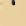




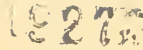 \\ PRICE LIST}

TERMS: Cash with Order. All items prepaid in U. S. Where Total Order Amounts to $\$ 3.00$

Special discount for orders by 100 or 1000 . Write for prices of what you want.

Any plant listed will stand 30 degrees below zero.

Achillea millifolium: White flowers. $8 \mathrm{c}$ each $80 \mathrm{c}$ Doz. Allium reticulatium: A pretty dwarf white-flowering form that blooms nearly all summer. Very hardy, 5c each $50 \mathrm{c}$ per doz.

Anemonie patens: Require a gravely soil and grows in sun or shade. They appear shortly after snow disappears. They are commonly called "Wild Crocus" owing to their many striking similarities to the Crocus. The flowers range in color from almost white through blue to bluish purple. 5-6 in. $10 \mathrm{c}$ each, $\$ 1.08$ per doz.

Antennaria umbrinella: A low perennial with whitish flowers nearly all summer. $8 \mathrm{c}$ each, $80 \mathrm{c}$ per doz.

Aquilegia canadensis: One of our prettiest wild flowers. with yellow and red flowers an inch long. 10c each, $\$ 1.00$ per doz.

Aragalus Lambertii: A low growing plant with red-purple to blue or white flowers in May. Leaflets silvery. $10 \mathrm{c}$ each, $\$ 1.00$ per doz.

Artemesi frigida: A silvery low growing plant that will do well in any good garden soil. $8 \mathrm{c}$ each, $80 \mathrm{c}$ per doz. Astragalus trphylus: A low growing silver leaf plant with white flowers. These have to be sent in small seedlings as larger plants will not transplant: Blooms in May. Found growing in a clay soil.. 5c each, $50 \mathrm{c}$ per doz.

Cactus Missourienis: A cushion sort with yellow flowers. $8 \mathrm{c}$ each, 80c per doz.

Cactus viviparus: A cushion sort with purple flowers. $8 \mathrm{c}$ each, $80 \mathrm{c}$ per doz. 
Cactus Clumps: Oftimes these are found in clumps of from 3 to sometimes as high as 30 or more. There will re one large one in center with small ones around it. These I will sell at the following prices:

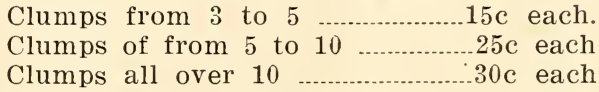

Calconortus Nuttallii: "Mariposa Lily" is a very desirable plant grows on southern slope of hills in rocky soil. $5 \mathrm{c}$ each $50 \mathrm{c}$ per doz.

Castilejia sessiliflora: $10 \mathrm{c}$ each, $\$ 1.00$ per doz.

Cerastium arvensea: A low growing plant with white flowers, blooms in early summer. Will do well in any good garden soil. 8c each, $80 \mathrm{c}$ per doz.

Cogswella Montana: A low growing plant that bears heads of white or yellow flowers nearly all summer. $5 \mathrm{c}$ each, $50 \mathrm{c}$ per doz.

Comendrea umbellata: Flowers like small white stars in clusters, will do well if given a sunny location. $8 \mathrm{c}$ each, S0c per doz.

Corydalis aurea Willd: Flowers yellow May and June $10 \mathrm{c}$ each, $\$ 1.00$ per doz.

Campanula rotundifolia: The Little Harebell. Well known and beloved. $8 \mathrm{c}$ each, $80 \mathrm{c}$ per doz.

Delphinum bicolor: Low Larkspur. $10 \mathrm{c}$ each, $\$ 1.00$ per doz.

Dodecatheon acuminatus: A pretty, perennial with white flowers in May or June. Found growing in moist places in full sun. $10 \mathrm{c}$ each, $\$ 1.00$ per doz.

Dodecatheon salium: In several shades of rose. 5c each, $50 \mathrm{c}$ per doz.

Disporum trachycarpum: White bell flowers, grows in shade. $10 \mathrm{c}$ each, $\$ 1.00$ per doz.

Erigeran pumilus: White, Daisy with yellow center, it blooms in June. $10 \mathrm{c}$ each, $\$ 1.00$ per doz,

Eriogonium flavum: Yellow flowers in June. 10c each, $\$ 1.00$ per doz. 
Erysium asperum: "Western Wallflower", yellow flowers in June. Give a sunny location. 8c each, $80 \mathrm{c}$ per doz.

Fritillaria autropurpurea: A dainty three-petaled purple and mottled nodding flower, grows from a bulb in a soft sand. Is a very desirable plant and easily grown in cultivation. $5 \mathrm{c}$ each, $50 \mathrm{c}$ per doz.

Gailardia aristata: A yellow Daisy with brown center, blooms in July. $12 \mathrm{c}$ each, $\$ 1.25$ per doz.

Galium boreale: White flowers in June. 10c each, $\$ 1.00$ per doz.

Gaura cocinea Pursh: A low growing plant with scarlet blossoms in June and July. 8c each, 80c per doz.

Gutierrizia: Yellow flowers in fall. 10c each, $\$ 1.00$ per doz.

Heucheria: The beauty of this plant is in the foliage in that it stays green nearly all year. Will do well in both sun or shade. 8c each, $80 \mathrm{c}$ per doz.

Lepachy Columnaries: Yellow cone flower. $8 \mathrm{c}$ each, $80 \mathrm{c}$ per doz.

Lesquerella alpina: A low growing plant with small yellow flowers in June. Found growing among rocks. $8 \mathrm{c}$ each, $80 \mathrm{c}$ per doz.

Lesquerella argeata: Have fine yellow flowers in early spring, give a sunny location. $5 \mathrm{c}$ each, $50 \mathrm{c}$ per doz.

Liatris: Are easily grown in cultivation and will repay you if given a good rich soil and a warm sunny location. Purple flowers in July and August. 8c each, 80c per doz. Linum perene: Another beautiful native. Very hardy and thrives well in any soil, producing a dense mass of stems covered with beautiful blue flowers in June and early July. $8 \mathrm{c}$ each, $80 \mathrm{c}$ per doz.

Lithospermum augustifolium: A low growing plant with pale yellow flowers from June until frost. $8 \mathrm{c}$ each, $80 \mathrm{c}$ per doz.

Lobelia spicata: Pale blue flowers with pale green leaves. Late fall. $8 \mathrm{c}$ each, $80 \mathrm{c}$ per doz. 
Lupin: Blue flowers in early spring. $8 \mathrm{c}$ each, $80 \mathrm{c}$ per doz.

Lupin flexucsus: Blue flowers in July. $12 \mathrm{c}$ each, $\$ 1.25$ per doz.

Malvastrum coccineum: Is a good little plant that takes readily to cultivation and improves greatly. The skeliton-like grayish leaves round out to a wonderful degree in cultivation. The orange scarlet little blossoms are like tiny single hollyhocks, about one inch across, bourne in terminal clusters which keep growing and blooming nearly all summer, give a sunny location. $8 \mathrm{c}$ each, $80 \mathrm{c}$ per doz.

Mentha piperita: Amaronatic plant found in moist places will grow in any moist garden soil. Blue flowers nearly all summer. 8c each, $80 \mathrm{c}$ per doz.

Mentzelia ornata: Have beautiful ten petaled white flowers that do not open untill evening. In a letter from Mrs. Wilder she says hers were perfectly beautiful. $8 \mathrm{c}$ each, $80 \mathrm{c}$ per doz.

Opuntia humifusa: Very hardy, flowers yellow. June and July. $10 \mathrm{c}$ each, $\$ 1.00$ per doz.

Oreocarya affinis: White flowers in May and June. $8 \mathrm{c}$ each, $80 \mathrm{c}$ per doz.

Pentstemon acuminatus: Rises to a foot in height and bears beautiful widemouthed violet-blue trumpets in a handsome spike. $10 \mathrm{c}$ each, $\$ 1.00$ per doz.

Pentstemon albidus: "White Beard Tongue." $10 \mathrm{c}$ each, $\$ 1.00$ per doz.

Petalostemum candida: White prairie clover. $8 \mathrm{c}$ each, $80 \mathrm{c}$ per doz.

Petalostenum purpurea: Violet prairie clover. $8 \mathrm{c}$ each, $80 \mathrm{c}$ per doz.

Picredaia aculis: A yellow daisy like flower with narrow silver leaves, blooms in June. $10 \mathrm{c}$ each, $\$ 1.00$ per coz.

Phlox alyssifolia: A low growing plant found on rocky hillside. Pink flowers changing to white, blossoms in Wiay. $10 \mathrm{c}$ each, $\$ 1.00$ per doz. 
Phlox hoodii: A charming gray-leaved white flowering dwarf, that blooms in May and June. Give a sunny location. 5c each, $50 \mathrm{c}$ per doz.

Potentilla pennsylvanica: A low growing plant with yellow flowers in May and June. 8c each, 80c per doz.

Pachylophus: Fragrant primrose. $10 \mathrm{c}$ each, $\$ 1.00$ per doz.

Ranunculis cymbalaria: A low growing plant with yellow flowers, blooms in May. 5c each, 50c per doz.

Ranunculis glaberrimus: A low growing plant with yellow flowers, blooms in May. $10 \mathrm{c}$ each, $\$ 1.00$ per doz.

Senecio fenderella: Yellow Daisy in cluster's, silvery foliage, blooms in June. 10c each, $\$ 1.00$ per doz.

Senecio worneriaefolias: Lighter leaves and narrow petals than S. fenderella. $10 \mathrm{c}$ each, $\$ 1.00$ per doz.

Siversia ciliata: Flowers rose to purple in June. Very scarce. $12 \mathrm{c}$ each, $\$ 1.25$ per doz.

Sisyrinchium augustifolium: Blue flowers. 5c each, 50c per doz.

Smilacina stellata: $8 \mathrm{c}$ each, $80 \mathrm{c}$ per doz.

Townsendia exscapa: “The Spring Daisy”. Mrs. Wilder says of this plant: "One of the most winning of wild flowers that have been sent me from the west. It makes a little dusty-looking splash of narrow leaves upon the ground upon which sits in May the most ample and lovely an innocent pink Daisy with a wide yellow eye." It is perfectly hardy and entirely delightful. 10c each, $\$ 1.00$ per doz.

Thermopsis Montana: 8c each, 80c per doz.

Tradescantia Virginica: Has pretty blue, three-petaled flowers from June until frost. $8 \mathrm{c}$ each, $80 \mathrm{c}$ per doz.

Viola: For early spring the native violets are unsurpassed in beauty. The blue will stand either sun or shade and is greatly enlarged by cultivation, blooms in late May and early June. 8c each, $80 \mathrm{c}$ per doz.

Viola Nuttallii: A very low growing sort with yellow flowers. Grows in the open. 8c each, 80c per doz. 
Viola bellidifolia: Blue flowers. $10 \mathrm{c}$ each, $\$ 1.00$ per doz. Viola pedatifida: Found growing in the open. Blue flowers in June. 10c each, $\$ 1.00$ per doz.

Yucca glauca: Has stiff, sharp, evergreen foliage with many white to cream color flowers on strong erect stems, give a sunny location, blooms in July. 10c each, $\$ 1.00$ per doz.

\section{SHRUBS}

All Shrubs are $15 \mathrm{c}$ each, $\$ 1.50$ per doz.

Lepargyraea: . Silvery foliage. Red berries.

Prunis demissa: White flowers in racems, fruit dark purple to black, good for jelly.

Red Dogwood.

Symphoricarpos racemosa:

Wild Plum:

Wild Rose: Both the tall and dwarf.

Bitter Sweet:

\section{VINES}

Clematis: White flowers.

Wild Grape:

Woodbine:

All plants that are $50 \mathrm{c}$ per dozen are $\$ 3.60$ per 100 . All plants that are $80 \mathrm{c}$ per dozen are $\$ 6.00$ per 100 . A'! plants that are $\$ 1.00$ per dozen are $\$ 7.50$ per 100 . Fifty Plants at 100 rate. 
THALICTRUM. - Beautiful fern Lke foliage resembling that of columbine. Has a dense clumx of roliage surmounted by feathery tuft of blossoms. -10 each $\$ 1.00$ per.doz.

BOITONIA.- A beautiful August blooming Give perennial with masses of small white, aster-like flowers. Grows in dense clump..........-10\% eaen \$1.00 per.do\%.

TALI BIUE ASTER-Another beaut ifuI native attalning a reight or 3 to 5 feet. 10; each $\$ 1.00$ per.doz.

BLUE UPIAIND ASTER. - This is one of the handsomest of the native asters, dwarf in habit extremely proruse bloomer, with large blue yellow-centered flowers. 12 to 24 inches.......-10\% each \$1.00 per. d9\%.

The following are not natives.

AQUIIEGIA.-Various colors, a rine mixture Thrifty plants, $8 \%$ each, lare sise, $15 \%$. clumps $20 \%$ to $30 \%$.

HOIIYHOCKS-Various colors, a fine mixture Thrifty plants, s\& each, lare size, $15 \%$. 
GYPSOPHIIA panculata.-.-Thrifty plants, 8* each, lare size, 15\%.

IINARIA.-Yellow Plowers.Thrifty plants, 8f each, lare size, 1t\%.

ROSEMARIUS officinalis. Thrifty plants, lok eacr, laro size, $20 \%$. 
